\title{
REVIEWS
}

\section{Epidemiology, Diagnostics and Treatment of Vascular Tumours and Malformations}

\author{
Clinic of Plastic Surgery, Wroclaw Medical University, Polanica Zdrój, Poland
}

A - research concept and design; $\mathbf{B}$ - collection and/or assembly of data; $\mathbf{C}$ - data analysis and interpretation;

$\mathbf{D}$ - writing the article; $\mathbf{E}$ - critical revision of the article; $\mathbf{F}$ - final approval of article; $\mathbf{G}$ - other

\begin{abstract}
Vascular tumours and vascular malformations are common vasculose anomalies characteristic for dissimilar clinical course, specific biological as well as immune cytological and histological properties. Vascular lesions classification system and their detailed division into groups and subgroups were elaborated and implemented in Rome, in 1996, during meeting of the International Society for the Study of Vascular Anomalies (ISSVA). It was based on modification of an earlier going division by Mullikien and Głowacki from 1982. Infantile hemangiomas are the most numerous group of benign tumours of mesenchymal origin. Vascular malformations appear definitely less often. They are composed of normal endothelium lined displastic vessels which originate from vascular tissue abnormal morphogenesis. In contrast, in hemangiomas, at the proliferation stage, increased, multiplication of endothelial cells is observed as well as of fibroblasts, mastocytes and macrophages. Infantile hemangiomas are usually not present at the moment of birth and white chloasma with superficial teleangiectasis appears which increases within 3-4 weeks and gets bright red colour and reveal very characteristic clinical course basing on intensive growth period and involution long process. Vascular malformations are observed most often at the delivery moment or they may appear at an early childhood. They enlarge proportionally along with the child's growth and their sudden expansion may be triggered by an infection, hormonal changes or trauma. Contrary to hemangiomas, they do not subside spontaneously and their abrupt increase may result in impairment or deformation of important anatomical structures. Infantile hemangiomas and vascular malformations require different and individual treatments which are often multi-stage procedures carried on in specialistic centres of plastic surgery, vascular surgery or maxillofacial surgery (Adv Clin Exp Med 2014, 23, 3, 475-484).
\end{abstract}

Key words: vascular tumours, vascular malformations, infantile hemangiomas, vascular anomalies.

Vascular tumours and malformations are common vasculose anomalies characteristic not only for their dissimilar clinical course but also for their specific biological, immune cytological and histological properties. Very often, they call for an individual and often multi-specialist treatment programme.

Infantile hemangiomas are the most numerous group of benign tumours of mesenchymal origin, which occur in 5-10\% of all neonates and in 30\% of prematurely born children [1]. They are found 3-9 times more often in girls than in boys [2] (Fig. 1A, B). Vascular malformations appear definitely less often with the same frequency for both sexes [3]. They are composed of normal endothelium lined dysplastic vessels which originate from vascular tissue abnormal morphogenesis [3]. Quite dissimilarly, in infantile hemoangimas, at the proliferation stage, the increased multiplication of endothelium cells, fibroblasts, mastocytes and macrophages is observed $[4,5]$.

In $80 \%$ of cases, hemangiomas are single lesions observed dominantly on body integuments with their most common location on the head (60\%), trunk (25\%) and limbs (15\%) [6]. However, they are usually not apparent at the moment of birth. Then, in their formation site, a white chloasma appears characterized by its superficial teleangiectasis. In the case of superficial hemangiomas, the chloasma increases within 3-4 weeks and takes on a bright, red color. More deeply seated hemangiomas, or those of organic location, appear well 


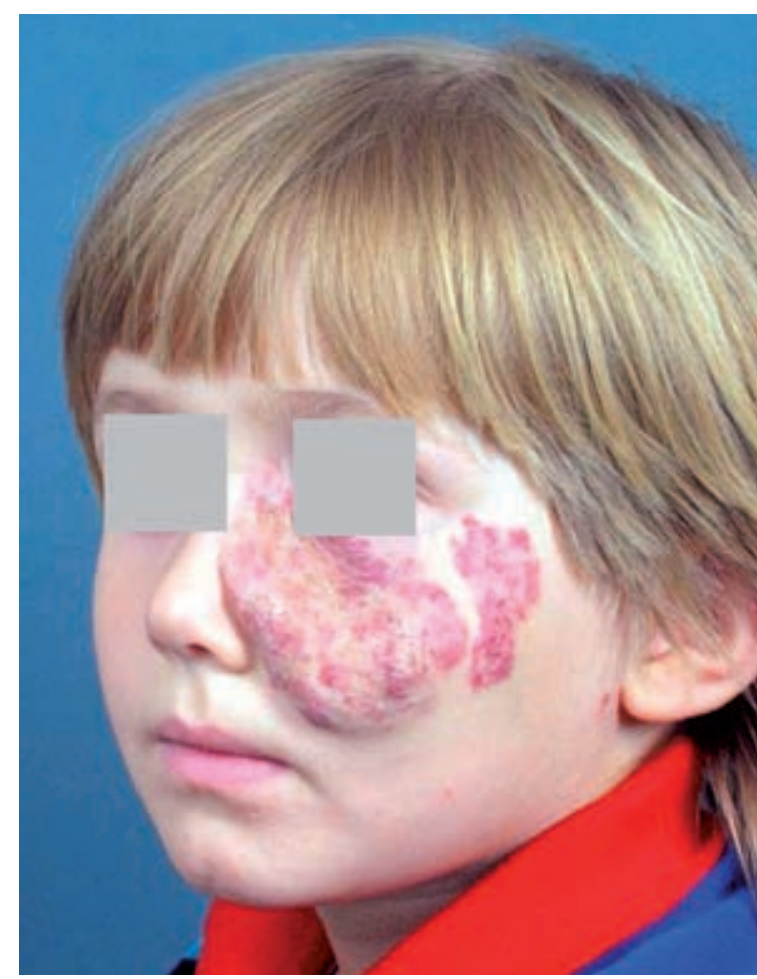

Fig. 1A. Hemangioma of the cheek (11-year old patient) - before treatment

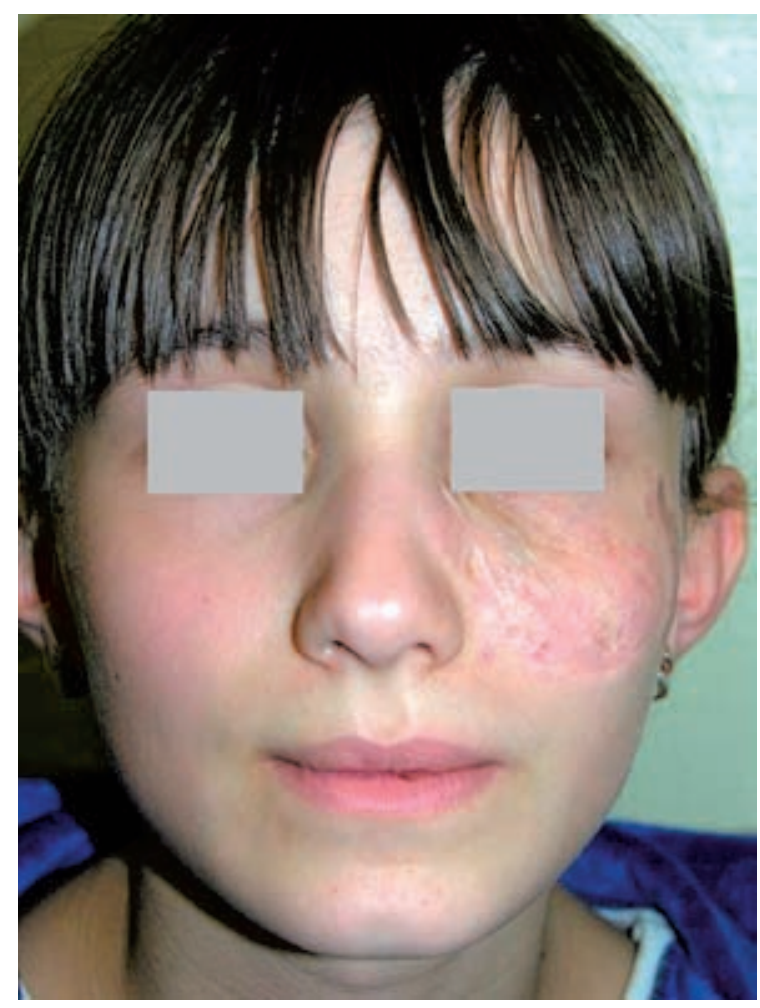

Fig. 1B. Hemangioma of the cheek (16-year old patient) - after treatment

after and their growth process is prolonged. In children who reveal a fully developed tumour at the moment of birth, the disease impetous course is more probable and it may result in major cicatrisation on dermis large area [7].
Hemangiomas are very characteristic for their clinical course of intensive growth and long involution process. In their complex cycle of transformation, the following consecutive stages can be distinguished: prologue $\left(6^{\text {th }}-9^{\text {th }}\right.$ week of foetal life], proliferation $\left(3^{\text {rd }}-10^{\text {th }}\right.$ month of infant period $)$, early involution $\left(1^{\text {st }}-5^{\text {th }}\right.$ year of life) and late involution which ends about the age of 10-12 [8]. Infantile hemangiomas appear usually at about the $2^{\text {nd }}$ week of life and they enlarge abruptly within the following 6-10 months [9]. In the majority of patients, they reach $80 \%$ of their size at the age $3.2( \pm)$ 1.7 months [10]. At the proliferative phase: endothelium cells, fibroblasts, mastocytes and macrophages multiply very intensively [11]. At this stage, the majority of hemangiomas require neither surgical intervention nor the employment of any treatment method. Regular check-ups are indicated as well as adequate care and control of the lesions. In $16 \%$ of children, ulcerations occur at the stage of the most intensive growth and they may result in pain, local infection, bleeding or unaesthetic scars [12]. They are provoked by skin injuries caused by tumour mass or ischaemia resulting from pathological arteriovenous leakages. Hemangiomas located in injuries mostly susceptible areas (lips, neck, perineal area) undergo ulcerations more often. In these cases, both special care and injury protection are recommended with particular reference to skin hygiene.

The application of the "wait and see" method or the administration of contingent local treatment are not possible actions in all patients. In the group of children with hemangiomas comprising all-important anatomical structures (orbit area, respiratory tract or lips), early surgical intervention or intensive systemic treatment administration are indispensable. They should be carried out in order to avoid potential complications: amblyopia, astigmatism-orbit area hemangiomas; food intake restriction-lips hemangiomas, and even life-threating complications (acute respiratory failure-subglottis area hemangiomas).

After the period of intensive growth, at the age of 9-12 months, the majority of hemangiomas reach the plateau stage being a stabilization phase followed by the involution phase characteristic in the sudden drop of endothelium cells and fibro-fatty tissue predominance [13]. In this period, tumour blanching and fattening appear and grey striae occur superficially. Hemangiomas redevelopment is usually completed after the age of 10-12 [8].

The course of the disease, particular stages of duration, lesions dynamics and final appearance are very individual and rather unpredictable for each patient. In about $70-80 \%$ of cases, hemangioma is supposed to involute without any permanent consequences calling for surgical correction [14]. 
Infantile hemangiomas specific cyclic development and involution are characteristic features differentiating them from vascular malformations $[15,16]$.

Vascular malformations are observed most often at the moment of birth or they may appear in early childhood. They enlarge proportionally to the child's growth and their sudden expansion may be triggered by an infection, hormonal changes or trauma [17]. Contrary to hemangiomas, vascular malformations do not regress spontaneously and their abrupt increase may result in the impairment or deformation of integral anatomical structures, osseous deformities (slow flow malformations), osteolysis (rapid flow malformations), respiratory tract obturation (neck or head malformations), infection, pain, thrombosis (venous malformations) or ulceration [18]. In some cases, they result in the disseminated intravascular coagulation process, pulmonary thrombosis, thrombocytopenia and even heart failure.

\section{Vascular Anomalies Classification}

Vascular tumours and malformations are the two groups of anomalies of absolutely different aetiopathogenesis and clinical course. Vascular lesions classification system and their detailed division into groups and subgroups were elaborated and implemented in Rome, in 1996, during the International Society for the Study of Vascular Anomalies (ISSVA) [19]. However, it was based on the modification of an earlier division by Mullikien and Głowacki from 1982 [11]. Until then, vascular anomalies had been misdiagnosed or misclassified, which resulted in improper diagnosis and treatment. In the previous century, vascular anomalies were still directly associated with a mother's emotional condition or her diet. For many years, there were strictly descriptive designations referring to the lesion appearance e.g. cherry hemangioma, strawberry hemangioma and others. Quite similarly, generally accepted and popular terms like "cavernous hemangioma" or "capillary hemangioma" are incorrect. Although vascular anomalies aetiological and pathogenetic recognition is still increasing, complex mechanisms of their formation have not been fully explained yet.

Apart from the most common infantile hemangiomas, the group of vascular tumours comprises congenital hemangioma [RICH-rapidly involuting congenital hemangioma and NICH-non involuting congenital hemangioma], kaposiform hemoangioendotheliomas and pyogenic granulomas.

In accordance with an obligatory classification and in relation to the formation of vessels, vascular malformations are divided into capillary, venous, lymphatic, arterial and hybrid ones. In respect to the blood flow rate, they are classified into high-speed flow and low-speed flow malformations. High-speed flow malformations include: arterial, arteriovenous and hybrid malformations. Low-speed flow malformations are capillary malformations, venous, lymphatic or hybrid malformations. Table 1 presents a detailed division of vascular anomalies.

Table. 1. Classification of vascular tumors and malformations

\begin{tabular}{|c|c|c|}
\hline \multirow[t]{2}{*}{ Vascular tumors } & \multicolumn{2}{|c|}{ Vascular malformations } \\
\hline & slow flow & fast flow \\
\hline Infantile hemangioma & \multirow{2}{*}{$\begin{array}{l}\text { capillary malformation: } \\
\text { cutis marmorata telangiectatica congenita } \\
\text { teleangiectasias }\end{array}$} & \multirow{3}{*}{$\begin{array}{l}\text { arterial malformation: } \\
\text { aneurysm } \\
\text { atresia } \\
\text { ectasia } \\
\text { stenosis }\end{array}$} \\
\hline Congenital hemangioma: & & \\
\hline angioma & \multirow{2}{*}{$\begin{array}{l}\text { lymphatic malformation: } \\
\text { microcystic } \\
\text { macrocystic }\end{array}$} & \\
\hline gioma & & \multirow{3}{*}{$\begin{array}{l}\text { arteriovenous malformation: } \\
\text { capillary malformation - arterio- } \\
\text { venous malformation } \\
\text { hereditary hemorrhagic telangi- } \\
\text { ectasia } \\
\text { PTEN-ssociated vascular anomay }\end{array}$} \\
\hline $\begin{array}{l}\text { Hemangioendotheliomas: } \\
\text { Kaposiform hemangio-endotheli- } \\
\text { oma }\end{array}$ & \multirow{2}{*}{$\begin{array}{l}\text { venous malformation: } \\
\text { cerebral cavernous malformation } \\
\text { cutaneomucosal venous malformation } \\
\text { glomuvenous malformation } \\
\text { verrucous hemangioma }\end{array}$} & \\
\hline \multirow{2}{*}{$\begin{array}{l}\text { Others } \\
\text { Pyogenic granuloma }\end{array}$} & & \\
\hline & $\begin{array}{l}\text { combined malformation: } \\
\text { capillary-venous malformation } \\
\text { capillary-lymphatic maformation } \\
\text { capillary-lymphatic-venous malformation }\end{array}$ & $\begin{array}{l}\text { combined malformation: } \\
\text { capillary-lymphatic arteriovenous } \\
\text { malformation }\end{array}$ \\
\hline
\end{tabular}


Therapies of vascular tumours and malformations are based on absolutely different procedures; thus, a correct diagnosis and appropriate differential diagnostic investigations are essential. Usually, a diagnosis can be based on a physical examination and medical history of the patient. In ambiguous and borderline cases, visual diagnostics (USG, CT, MR) as well as histopathological examination are recommended. An absolutely different clinical image is also very helpful in lesion differentiation. After the phase of initial growth, infantile hemangiomas usually undergo a complete regression and do not require any treatment. Malformations do not involute spontaneously and, in the majority of cases, the tumour abrupt expansion is observed and surgical treatment is required [20].

\section{Theories of Infantile Hemangiomas Formation and Syndromes Commonly Coexisting with Vascular Tumours}

Vascular abnormalities of infantile hemangiomas result from very complex mechanisms, which occur between the $6^{\text {th }}$ and the $10^{\text {th }}$ week of foetal life, which is known as the vasculogenesis period. The majority of lesions appear spontaneously and are not hereditary [21].

Hemangiomas endothelial cells - hemECs are in some researchers' opinion monoclonal cells resulting from spontaneous mutations [22] and they largely influence vascular tumour proliferation and development. However, being in the overwhelming majority, the opponents of this theory claim that hemECS are polyclonal and they act as normal endothelial cells. In their opinion, hemECS undergo abnormal and excessive proliferation due to the in-cells activity or the influence of hemangioma adhering cells (e.g. macrophages, fibroblasts). The process may also result from the disturbed balance between pro-angiogenetic factors and angiogenesis inhibitors [23]. VEGF and bFGF [24], metalloproteinases 2 and 9 [25], angiopoietins (Ang-1, Ang-2) - acting by localization of tyrosine kinase specific receptors [26], insulin resembling growth factor (IGF-2) and E-selectin [27] play the most important role among angiogenesis promotors. The theory of hemangioma placental origin suggests that foetal vessels embolization with the placental origin cells is a direct reason for tumour formation. The presence of GLUT 1-glucose transporter molecule 1 [28] in hemangiomas tissues is the main argument for this assumption. What is more, hemangiomas were found 3-4 times more often in children delivered by mothers who had undergone chorion or trophoblast biopsy [29]. The development of hemangiomas may be induced by hormonal transformations and it concerns especially the ones related to estrogen and its derivatives [30].

According to other theories, hemangiomas may not only result from sequestration and autonomic proliferation of multipotential angioblastic cells [31] but also from developmental field disturbances. This may be evidenced by hemangiomas coexistence with other developmental malformations e.g. PHACE syndrome and other rare anomalies: Kasabach-Merritt's Syndrome. PHACE syndrome is the acronym (abbreviation) formed of initial letters of developmental anomalies denominations: posterior fossa brain malformation, hemangioma, arterial cerebrovascular anomalies, coarctation of the aorta and cardiac defect and eye/ /endocrine abnormalities. In children with sternal clefting or supraumbilical raphe, the syndrome name is turned into PHACES [32].

In rare Kasabach-Merritt's Syndrome, abruptly growing tumour is accompanied by haemolitic anaemia, thrombocytopenia and coagulopathy. Vascular anomaly is usually Kaposi haemagioendothelioma [33].

Skin sheaths hemangiomas may coexist with internal organs hemangiomas, which are situated mainly in the liver, mediastinum or retroperitoneal area. In such locations, their course is usually very abrupt and uncontrolled and may result in anaemia or circulatory failure. Hemangiomas of internal organs occur mainly in diffuse hemangiomatosis patients or those with extensive vascular lesion in the craniofacial area.

Vascular malformations genesis is strictly connected with vascular tissue morphogenesis abnormal course. Depending on a predominant vascular component, the following types are distinguished: capillary, venous, arterial, lymphatic and hybrid malformations. The malformations are divided into low and high-speed flow in respect to the rate of the blood flow.

\section{Capillary Malformations}

Capillary malformations are often compared to the stain of red wine. They occur in $0.3 \%$ of all children with the same prevalence frequency for both sexes [34] (Fig. 2 A, B). Their formation mechanism has not been fully recognized yet. One of the most probable theories coming from the $19^{\text {th }}$ century (neuro-vegetative theory) claims that there are primary disturbances of vessels development 


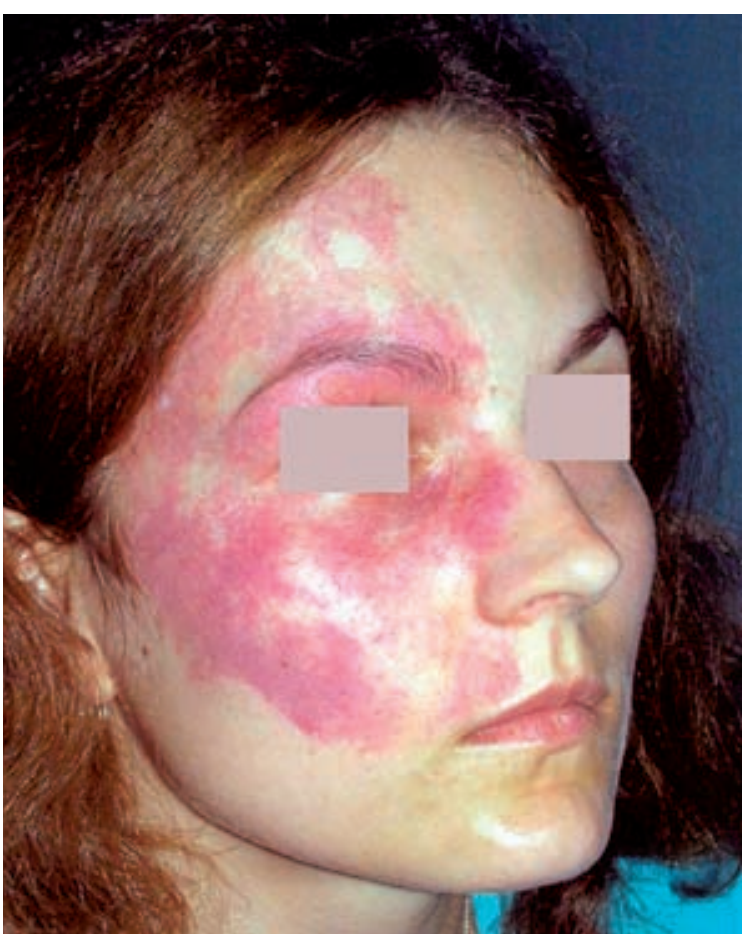

Fig. 2A. Capillary malformation of the face (26-year old patient) - before treatment

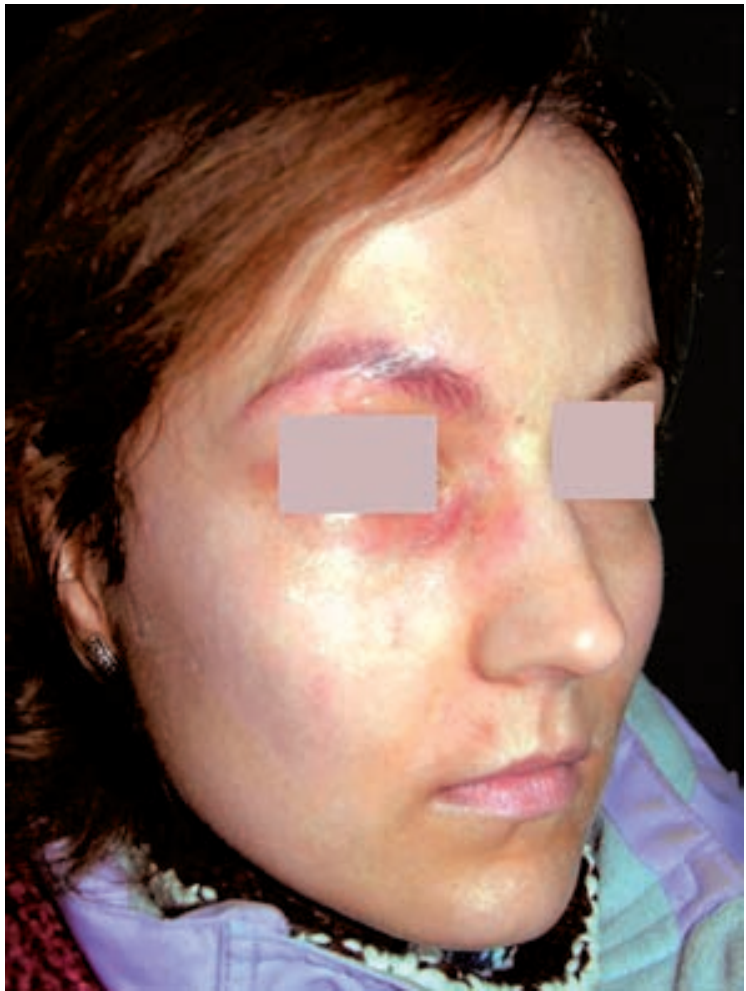

Fig. 2B. Capillary malformation of the face (29-year old patient) - after treatment

prevailing in the sites of autonomic nervous system formation [35]. This may be manifested by frequent capillary malformations in the areas supplied by trigeminal nerve branches that is in segments of peripheral nervous system or by increased sweatiness in diseased regions [36]. Many scientists claim that "a red wine stain" results from capillaries contractility loss caused by sympathetic innervation disturbances. Capillary malformations are observed on the whole body surface in local or extensive forms. Very rarely, they form general multifoccal skin lesions like Sturge-Weber Syndrome.

Usually, they can be observed in a form of a small pink spot at the moment of birth which turns pale when pressed. It changes into dark red in young adults and with time; it turns into black navy blue with numerous cuspal and fibrovascular lesions on the surface.

In $45 \%$ of cases, malformations located on the face are limited to one out of three regions innervated by trigeminal nerve branches [37]. In the remaining patients, they either exceed the midline or occur bilaterally. Very often, they can cause soft tissues hyperplasia (lips, cheeks, glabella area and even osseous structures like mandible or maxilla) [38]. Face lesions are usually accompanied by gums and oral mucosa hyperplasia or even pyogenic granuloma which may result in ulcerations or recurrent haemorrhages.

Capillary malformations are also observed on trunk and limbs. Contrary to face stains, they do not undergo characteristic transformations in the form of structure and colour changes. In many cases, they are an alarming signal before the appearance of other developmental lesions such as: spinal cord arteriovenous malformations in the course of thorax capillary lesion (Cobb's syndrome) [39] or latent cleft spine in case of visceral or lumbosacral area malformations [40].

\section{Lymphatic Malformations}

Lymphatic malformations result from the abnormal development of the lymphatic system: lymphatic structures separate from the main stem or they get formed de novo outside anatomical location of lymhoid tissue. Due to conjoint embriological origin of venous and lymphatic systems, venolymphatic malformations can be observed [41].

Lymphatic malformations are usually found at the moment of birth or up to the age of two. Quite exceptionally, they appear later in early childhood, puberty and even maturity, and their most common locations are the head, neck, axillary space, thorax and perineal areas. They are soft and their abrupt hyperplasia is often connected with an injury, hormonal disturbances or infection. There are several systems of malformations classification. Morphological division being the most popular as it distinguishes the lesions into microcystic, 
macrocystic malformations (big enough to undergo paracentesis procedure or sclerotherapy) and hybrid ones.

Appreciating the lesion location in reference to hyoid muscle, McGill distinguished malformation type I: below hyoid muscle, in the anterior or posterior neck triangle and malformation type II: above the hyoid muscle and comprising the tongue, cheeks, parotid salivary gland or lips [42].

Bleeding and infections are the most common complications, accompanied by oedema and pain [43].

In the case of more extensive lesions, deformations, obturations and damages of very important structures, like the respiratory tract or orbital area, may occur. Similarly to venous malformations, lymphatic lesions may cause soft tissues hyperplasia of e.g. the tongue or even osseous tissues. In abdominal lymphatic anomalies patients, lymph accumulation within pericardium and pleural or visceral cavities can be observed. In rare cases, the disease has generalized extension and comprises a vast section of gastrointestinal tract (intestinal lymphangiectasis) or dispersed lesions in skeletal system: Gorham-Stout Syndrome - so called vanishing bone disease or phantom bone disease [44]

\section{Venous Malformations}

Venous malformations result from abnormalities of vessels formation process. Most often, single malformations are found ( $90 \%$ of patients) in the region of the head and neck (47\%) and in the trunk area (13\%) [45]. Almost always, they affect the skin, subcutaneous tissue, mucous membrane and deep structures, such as muscles, articulations and bones [45].

Venous malformations are black and blue, soft and susceptible to pressure and non-pulsating lesions. They are built of thin walled and widened vessels of normal endothelium and thinned out muscular layer [35]. They grow along with age and their sudden expansion may be connected with infection, trauma or hormonal changes (puberty or pregnancy).

Due to the blood slow flow or stagnation in big and wide venous compartments, the possibility of thrombi formation or intravascular dispersed coagulopathy should be considered. In such cases, special precautions should be taken before the operative procedure.

Pain and oedema are the most common complications in venous malformations patients. In those with face and neck extensive malformations, compression type symptoms may appear in the area of the eyeball or the respiratory tract and may require immediate medical intervention. Big venous malformations located in the limbs can cause deformities, tissue atrophy related hypoplastic lesions, pathological fractures and joints degenerations [46]. In the case of digestive tract multi sectional involvement, many patients are diagnosed with chronic anaemia resulting from bleeding to the stomach or intestinal lumen.

\section{Arteriovenous Malformations}

They are caused by abnormalities in vessels formation between the $4^{\text {th }}$ and $6^{\text {th }}$ week of foetal life [35]. The abnormalities (according to Halsted) are based on a lack of apoptosis of arteriovenous junctions in the primary foetal vascular plexus or the absence of capillaries rete formation [47]. This mechanism may account for the twenty-fold more frequent prevalence of arteriovascular anomalies in the central nervous system, where apoptosis processes are sporadic [48].

Apart from the central nervous system, arteriovascular malformations appear on the head and neck and less frequently on limbs, trunk or internal organs [40]. They are observed at the moment of birth, usually in the form of small pink spot (often mistaken for angioma or capillary malformation). However, they often come out only in later childhood. This is caused by the sudden growth of the tumour (especially in the maturation period) and is accompanied by symptoms such as bleeding, pain and ulceration.

Malformation hyperplasia is an abnormal reaction of vascular structures to an increase in blood pressure: vascular system collateralization, vessels widening, neighbouring veins and arteries thickening [49]. It also results from the processes of angiogenesis (new blood vessels formation from vascular precursors) and vasculogenesis (vessels de novo formation) [50]. Vessel formation is both the reason for arteriovenous anomalies expansion but also its possible result (like the increase of the level of vascular and endothelial growth factor (VEGF) and enhanced proliferation of endothelium cells [51].

Arteriovascular malformations may cause tissue deformities and obturation of important anatomical structures, such as abdominal or respiratory tracts. Major and dangerous complications comprise: varicose veins bleeding, aneurysms formations, increase or even insufficiency of heart muscle caused by direct connection of hypertensive arterial system and hypotensive venous system.

All arteriovascular malformations may be divided into 4 groups in respect of their stage and 
Table. 2. Schobinger classification

\begin{tabular}{|l|l|l|}
\hline \multicolumn{3}{|c|}{ Schobinger classification } \\
\hline I & quiescence & AV shunting \\
\hline II & expansion & thrill, pulsation, bruit \\
\hline III & destruction & ulceration, bleeding, pain \\
\hline IV & decompensation & high output cardiac failure \\
\hline
\end{tabular}

clinical symptoms (as per Schobinger) [52] (Table 2). If arteriovascular malformations are left untreated they may progress with growth, bleeding and even high output cardiac failure due to the rapid transit of blood through the arteriovascular, bypassing the rest of the body and returning rapidly to the heart.

Sturge-Weber's Syndrome is the most common syndrome accompanying vascular malformations and capillary malformations in particular. Most often, it occurs in the face region innervated by ramus I (ophtalmic) and ramus II (maxillary) of trigeminal nerve. Only in very rare cases, the malformation affects all dermatomic areas innervated by the nerve three ramifications. In maxillary distribution patients (ramus II of trigeminal nerve) and mandibular distribution (ramus III of trigeminal nerve), the risk of Sturge-Weber's syndrome prevalence is small. Apart from dermal manifestation, dura mater and arachnoid plexus anomalies are observed. They appear in the form of capillary, venous and arteriovenous malformations. Small lesions do not provoke any clinical symptoms, whereas bigger ones may cause palpitations, epileptic seizure, one-sided hemiplegia and impaired psychomotor impairment. Sturge-Weber's Syndrome lesions may also comprise uvea and, in more severe cases, they may cause glaucoma, retinal detachment or loss of vision. This is why, for every patient with "red wine stain" in the area innervated by ramus I or II, it is especially important to be diagnosed carefully and, in the case of a positive diagnosis, to be consulted neurologically, ophtalmologically and surgically.

\section{The Treatment of Infantile Hemangiomas and Vascular Malformations}

Vascular tumours and malformations constitute two basic groups of vascular anomalies characteristic for their dissimilar clinical and biological qualities and clinical course. They require distinct and individual kinds of treatment which are often multistage procedures carried out in specialistic centres of plastic surgery, vascular surgery or maxillofacial surgery.

Vascular anomalies treatment depends on many factors: vascular lesion developmental stage, patient's age and the lesion character, location and intensity, which are strictly connected with reconstruction possibilities.

In the majority of cases, hemangiomas appear in the form of single and not extensive lesions located on body integuments, which undergo total or almost complete involution and often do not require any treatment. They demand observation and regular check-ups at the proliferation stage and possible correction of the scar after the tumour involution.

However, even in the case of small lesions, complications are possible in the form of local bleeding or ulceration, which can be prevented by the proper care of the tumour skin and protection against injuries.

The majority of hemangiomas do not require treatment but sometimes, an increasing tumour can pose a danger to the health and even life of a patient. This is often observed in the case of tumours involving lips, orbital, respiratory tract or liver areas. In such cases, waiting for the involution period might have fatal consequences, so "predicting" tumour possible sequelae, the treatment is administered during the proliferation stage. In such cases, a surgical procedure is often necessary and is often preceded by the treatment with propranolol. Other non-surgical methods comprise of pulse dye laser, combined therapy or steroids (less and less frequently applied due to pain and undesired side effects). Propranolol's favourable influence on infantile henangiomas treatment was accidentally discovered by Léauté Labrèze in 2008, while its oral administration in hyperthropic obstructive cardiomyopathy is used in the case of children [53]. During the treatment, Labrèze observed a significant regression in nose hemangioma, which made her apply propranolol in other patients with congenital hemangiomas of orbital area. The therapy efficacy and results increased the interest in this new method of treatment, which has become very popular since that time [54-56]. Pharmacological treatment is carried out in ambulatory mode after preliminary hospitalization and cardiologic consultation, and it is usually initiated in the $2^{\text {nd }}$ $3^{\text {rd }}$ month of life, which is the hemangioma proliferation phase. Before treatment, a detailed medical history is taken with particular reference to the diseases, such as respiratory tract diseases, asthma, hypotension, bradycardia or diabetes, due to the drug possible side effects [57].

Propranolol is very well tolerated by infants. The patients' preliminary qualification as well as 
therapy proper planning brings excellent results and the treatment is practically devoid of any undesired side effects.

Most often, the therapy starts with an oral dose $-0.5 \mathrm{mg} / \mathrm{kg} /$ day (in three portions) which is gradually increased to $2 \mathrm{mg} / \mathrm{kg} /$ day (sometimes $3 \mathrm{mg} /$ $/ \mathrm{kg} /$ day). During the treatment, patients remain under medical control [58].

At present, in many centres, in patients with large and deforming infantile hemangiomas, propranolol treatment is the first line therapy [59]. It allows hemangioma significant reduction before the planned operative procedure. Small hemangiomas frequently involute after propranolol treatment administration and do not require further operative procedures. Due to the treatment positive results, high efficacy and rare undesired side effects, propranolol treatment more and more often replaces systemic or local steroid therapy.

The treatment of vascular malformations that do not involute spontaneously is absolutely different and often requires therapy in multi-speciality centres with adequate equipment facilities and specialist background, including plastic surgery, paediatric surgery, vascular surgery, maxillofacial surgery and interventional radiology. The therapy is usually very difficult because of the tumour's large size, its expansive growth and location, often close to important anatomical structures, such as orbits or respiratory tract.

Small and asymptomatic capillaries or lymphatic malformations can be observed during the child's first years and the decision about the treatment (laser therapy or surgical treatment) can be made hereafter.
At present, in the case of capillary malformations, pulsating laser therapy of high chemical affinity with oxyhemoglobin is the method of choice [60]. The treatment is multi stage and comprises of several sessions every 4-6 weeks and, in effect, helps to lighten up the lesion and improves aesthetics. In mandibular hyperplasia patients, orthodontic treatment is suggested and in more severe cases, orthognatic procedures are carried out.

In the case of small and medium venous or capillary malformations, Nd: YAG lasers [61] or diode lasers [62], [63] are used.

Extensive venous, lymphatic or arteriovascular malformations are health and life threatening. However, there is no one method of treatment. The therapeutic method depends on the type and extensiveness of the malformation, its clinical symptoms and patient's age. In many cases, total resection is not possible and the procedure must be divided into several stages. In the majority of patients with extensive lesions, surgical removal is preceded by malformation vessels sclerotization or embolization. The procedure consists of inserting an inflammatory agent into the vessel in order to provoke its cicatrization and lumen closure to avoid intra operative bleeding.

After several days, the subsequent phase comprises of resection and simultaneous reconstruction. In the case of small tumours, local plastic procedures reconstruct the structures, whereas more complex operations with the use of flaps transposition on microvascular conjunctions are applied in extensive lesions. Post-operative cicatrices can be successfully treated with $\mathrm{CO} 2$ fractionated laser ablation [64].

\section{References}

[1] Jacobs AH, Walton RG: The incidence of birthmarks in the neonate. Pediatrics 1976, 58, 218-221.

[2] Amir J, Metzker A, Krikler R: Strawberry hemangioma in preterm infants. Pediatr Dermatol 1986, 3, 331-332.

[3] Enjorlas O, Wassef M, Chapot R: Color atlas of vascular tumors and vascular malformations. Cambridge University Press, Cambridge 2007.

[4] Mulliken JB, Zetter BR, Folkman J: In vitro characteristic of endothelium from hemangiomas and vascular malformations. Surgery 1982, 92, 348-353.

[5] Wyrzykowski D, Chrzanowska B, Czauderna P: Congenital vascular anomalies in pre- and perinatal period of life-management and treatment options. Arch Perinatal Med 2011, 17, 85-92.

[6] Finn MC, Glowacki J, Mulliken JB: Congenital vascular lesions: clinical application of a new classification. J Pediatr Surg 1983, 18, 894-900.

[7] Szymik-Kantorowicz S. Naczyniaki - co o nich wiemy? Adv Clin Exp Med 2005, 14, 129-136.

[8] Mulliken JB: State of the Art and future trends-round table on hemangiomas. $10^{\text {th }}$ International Workshop on Vascular Anomalies, Budapest June 1994.

[9] Grochowski J, Szymik-Kantorowicz S: Nieprawidłowości naczyń obwodowych u dzieci. Chirurgia tętnic i żył obwodowych. Red. Noszczyk W, PZWL, Warszawa 1998, 502-508.

[10] Chang LC, Haggstrom AN, Drolet BA: Growth characteristics of infantile hemangiomas: implications for management. Pediatrics 2008, 122, 360-367.

[11] Mulliken JB, Głowaacki J: Hemangiomas and vascular malformations in infants and children: a classification based on endothelial characteristics. Plast Reconstr Surg 1982, 69, 412-422.

[12] Chamlin SL, Haggstrom AN, Drolet BA: Multicenter prospective study of ulcerated hemangiomas. J Pediatr 2007, 151, 684-689. 
[13] Takahashi K, Mulliken JB, Kozakewich H, Harry P, Rogers R, Folkman J, Ezekowitz R: Cellular markers that distinguish the phases of hem angioma Turing infanci and childhood. J Clin Invest 1994, 93, 2357-2364.

[14] Nakayama H. Clinical and histological studies of the classification and the natural course of the strawberry mark. L Dermatol 1981, 2, 277-291.

[15] Smoller BR, Apfelberg DB: Infantile (juvenile) capillary haemangioma: a tumor of heterogeneous cellular elements. J Cutan Pathol 1993, 20, 330-336.

[16] Sznurkowska K, Wyrzykowski D: Naczyniaki u dzieci - problem interdyscyplinarny. Forum Med Rodz 2011, 5, 460-467.

[17] Fishman SJ, Mulliken JB: Hemangiomas and vascular malformations of infancy and childhood. Pediatr Surg 1993, 40, $1177-1200$.

[18] Boyd JB, Mulliken JB, Kaban LB: Sceletal changes associated with vascular malformations. Plast Reconstr Surg 1984, 74, 789-797.

[19] Enjolras O, Mulliken JB: Vascular tumors and vascular malformations (new issues). Adv Dermatol 1998, 13, $375-423$.

[20] Enjolras O, Wassef M, Chapot R. Color atlas of vascular tumors and vascular malformations. Cambridge Univeristy Press, Cambridge 2007.

[21] Przewratil P: Naczyniaki krwionośne - aktualne teorie dotyczące patogenezy. Prz Pediatr 2009, 39, 39-41.

[22] Yu Y, Flint AF, Mulliken JB, Wu JK, Bischoff J: Endothelial progenitor cells in infantile hemangioma. Blood 2004, 103, 1373-1375.

[23] Frischer JS, Huang J, Serur A, Kadenhe A, Yamaschiro DJ, Kandel JJ: Biomolecular markers and involution of hemangiomas. J Pediatr Surg 2004, 39, 400-404.

[24] Walsh DA: Pathophysiological mechanism of angiogenesis. Adv Clin Chem 2007, 44, 187-221.

[25] Zhang GY, Yi CHG, Li X, Liang ZQ, Wang RX, Liu DE, Zhang LM, Meng CY, Guo SZ: Proliferation hemangiomas formation through dual mechanism of vascular endothelial growth factor mediated endothelial progenitor cells proliferation and mobilization through matrix metlloproteinases 9. Med Hypoth 2008, 70, 815-818.

[26] Yu Y, Varughese J, Brown LF, Mulliken JB, Bischoff J: Increased Tie2 expression enhanced response to angiopoietin-1 and dysregulated angiopoietin-2 expression in hemangioma-derived endothelial cells. Am J Pathol 2001, $159,2271-2280$

[27] Ritter MR, Dorell MI, Edmonds J, Friedlander SF, Friedlander M: Insulin-like growth factor 2 and potential regulators of hemangioma growth and involution identified by large scale expression analysis. Proc Natl Acad Sci USA 2002, 99, 7455-7460.

[28] North PE, Waner M, Mizeracki A, Mihm MC: GLUT-1: A newly discovered immunohistochemical marker for juvenile hemangiomas. Hum Pathol 2000, 31, 11-22.

[29] Burton BK, Schulz CJ, Angle B, Burd LI: An increased incidence of hemangiomas in infants born following chorionic villus sampling (CVS). Prenatal Diagn 1995, 15, 189-195.

[30] Lui W, Zhang S, Hu T, Wei F, Gao Y, Cheng N: Sex hormone receptors of hemangiomas in children. Chin Med J (Engl) 1997, 110, 349-351.

[31] Dadras SS, North PE, Bertoncini J, Mihm MC, Detmar M: Infantile hemangiomas are arrested in an early developmental vascular differentiation state. Mod Pathol 2004, 17, 1068-1079.

[32] Freiden IJ, Reese V, Cohen D: PHACE syndrome. The association of posterior fossa brain malformations, hemangiomas, arterial anomalies, coarctation of the aorta and cardiac defects and eye abnormalities. Arch Dermatol 1996, $132,307-311$.

[33] Enjorlas O, Wassef M, Mzoyer E, Frieden IJ, Rieu P, Drouet L, Taleb A, Stalder J, Escante J: Infants with Kasabach-Merritt syndrome do not have „true” hemangiomas. J Pediatr 1997, 130, 631-640.

[34] Johnston M: Radioautographic study of the migration and fate of cranial neural crests in the chick embryo. Anat Rec 1966, 156, 143-155.

[35] Mulliken JB, Young A: Vascular Birthmarks: Hemangiomas and Malformations. WB Saunders, Philadelphia 1988.

[36] Nozue T, Tsuzaki M: Further studies on distribution of neural crest cells in prenatal or postnatal development in mice. Okajimas Folia Anat Jpn 1974, 51, 131-160.

[37] Enjolras O, Riché MC, Merland JJ: Facial port-wine stains and Sturge-Weber syndrome. Pediatrics 1985, 76, 48-51.

[38] Greene AK, Taber SF, Ball KL: Sturge-Weber syndrome: frequency and morbidity of facial overgrowth. J Craniofac Surg 2009, 20, 617-621.

[39] Cobb S: Haemangioma of the spinal cord associated with skin nevi of the same metamere. Ann Surg 1915, 62, 641-649.

[40] Mulliken JB, Fishman SJ, Burrows PE: Vascular Anomalies. Curr Prob Surg 2000, 37, 517-584.

[41] Sabin F: On the origin of the lymphatic system from the veins and the development of the lymph hearts and thoracic duct in the pig. Am J Anat 1902, 1, 367-389.

[42] McGill TJ, Forsen JW, Mulliken JB: Hemangiomas and vascular anomalies of head and neck. Pediatr Otolaryng Head and Surg. Vol 5, cap V. Mosby, New York 1998, 66-80.

[43] Padwa BL, Hayward PG, Ferraro NF: Cervicofacial lymphatic malformation: clinical course, surgical intervention, and pathogenesis of skeletal hypertrophy. Plast Reconstr Surg 1995, 95, 951-960.

[44] Gorham L, Stout A: Massive osteolysis (acute spontaneous absorption of bone, phantom bone, disappearing bone): its relation to hemangiomatosis. J Bone Joint Surg Am 1955, 37, 986-1004.

[45] Boon LM, Mulliken JB, Enjolras O: Glomuvenous malformation (glomangioma) and venous malformation: distinct clinicopathologic and genetic entities. Arch Dermatol 2004, 140, 971-976. 
[46] Upton J, Coombs CJ, Mulliken JB: Vascular malformations of the upper limb: A review of 270 patients. J Hand Surg (Am) 1999, 24, 1019-1035.

[47] Halsted W: Congenital arteriovenous and lymphaticovenous fistulae: unique clinical and experimental observations. Proc Natl Acad Sci USA 1919, 5, 76-79.

[48] Gomes MM, Bernatz PE: Arteriovenous fistulae: A review and ten-year experience at the Mayo Clinic. Mayo Clin Proc 1970, 45, 81-102.

[49] Holman E: The physiology of an arteriovenous fistula. Am J Surg 1955, 89, 1101-1108.

[50] Liu AS, Mulliken JB, Zurakowski D: Extracranial arteriovenous malformations: natural progression and recurrence after treatment. Plast Reconstr Surg 2010, 125, 1185-1194.

[51] Masuda H, Zhuang YJ, Singh TM: Adaptive remodeling of internal elastic lamina and endothelial lining during flow-induced arterial enlargement. Arterioscler Thromb Vasc Biol 1999, 19, 2298-2307.

[52] Kohout MP, Hansen M, Pribaz JJ: Arteriovenous malformations of the head and neck: Natural history and management. Plast Reconstr Surg 1998, 102, 643-654.

[53] Léauté-Labrèze C: Propranolol for severe hemangiomas of infancy. N Engl J Med 2008, 358, 2649-2661.

[54] Taban M: Propranolol for orbital hemangioma. Opthalmology 2010, 117, 195.

[55] Fay A: Propranolol for isolated orbital infantile hemangioma. Arch Opthalmol 2010, 128, 256-258.

[56] Hermans DJ: Propranolol in a case series of 174 patients with complicated infantile hemangoma: indications, safety and future directions. Br J Dermatol 2013, 168, 837-843.

[57] Wyrzykowski D, Chojnicki M: Zastosowanie propranololu w leczeniu naczyniaków wczesnodziecięcych - doświadczenia własne. Standardy Medyczne/Pediatria 2010, 7, 100-105.

[58] Alison B: Infantile hemangiomas: A review. Saudi J Opthalmol 2012, 26, 283-291.

[59] Andrzejewska E, Bacewicz L: Zastosowanie propranololu w leczeniu naczyniaków krwionośnych wczesnodziecięcych - program wieloośrodkowej oceny skuteczności. Badania Wieloośrodkowe w Ogólnopolskim Rejestrze Chirurgii Noworodka.

[60] Ortiz AE, Nelson JS: Port-wine stain laser treatments and novel approaches. Facial Plast Surg 2012, 28, 611-620.

[61] Werner JA, Lippert BM: Ultrasound-guided interstitial Nd: Yag laser treatment of voluminous hemangiomas and vascular malformations in 92 patients. Laryngoscope 1998, 108, 463-470.

[62] Alvarez-Camino JC, Espana-Tost AJ: Endoluminal sclerosis with diode laser in the treatment of orofacial venous malformations. Med Oral Patol Oral Cir Bucal 2013 1, 18, 486-490.

[63] Klein A, Baumler W: A randomized controlled trial to optimize indocyanine gree-augmented diode laser therapy of capillary malformations. Lasers Surg Med 2013, 45, 216-224.

[64] Wolfenson M, Norberto dos Santos Fiho FC: Scar treatment with fractional laser. Plast Recostr Surg 2012, 130, 908-910.

\section{Address for correspondence:}

Karolina Wójcicka

Clinic of Plastic Surgery

Wroclaw Medical University

Polanica Zdrój

Poland

Tel.: 694426636

E-mail: kwojcicka4@poczta.onet.pl

Conflict of interest: None declared

Received: 17.06.2013

Revised: 3.10.2013

Accepted: 9.06.2014 